\title{
Evaluation of Susceptibility of Carnation Cultivars to Fusarium Wilt and Determination \\ of Fusarium oxysporum fsp. dianthi Races in Southwest Spain
}

\author{
Ana María Prados-Ligero \\ Protección de Cultivos, CIFA-Córdoba, Apartado 3092 (IFAPA), Spain
}

María José Basallote-Ureba

Protección de Cultivos, CIFA-Alcalá del Rio (Sevilla), Apartado 41200

(IFAPA), Spain

\section{Carlos José López-Herrera and José María Melero-Vara ${ }^{\mathbf{1}}$ \\ Protección de los Cultivos, IAS-Córdoba, Apartado 4084 (CSIC), Spain}

Additional index words. Dianthus caryophyllus, race differentials, resistance, vascular wilt

Abstract. Eighteen commercial cultivars of carnation were inoculated with eight isolates of $F$. oxysporum fsp. dianthi $(F o d)$ from a collection of isolates obtained from diseased plants surveyed in the main growing area of Spain. Susceptible reactions were shown in most cultivars inoculated with six isolates characterized as race 2 when tested on differentials. However, cultivars Elsy and Westcristal were fully resistant to the six isolates, whereas 'Scarlet King' showed a variable response, suggesting genetic diversity within race 2 of $\mathrm{Fod}$. In contrast, eight cultivars inoculated with three isolates of races 1 or 8 were usually resistant except for cultivars Nelson and Solar, which were fully susceptible, and 'Elsy', which showed resistance to only one of the isolates. Partial polygenic inheritance of resistance to race 2 determines the complexity in the host reactions. Nine cultivars used in the previous experiment were inoculated with 13 Italian isolates of a collection of races of $\boldsymbol{F o d}$. Cultivar reactions to isolates of different races agreed with some reports but not with others, suggesting an effect of environmental conditions or inoculation method. Reactions under field conditions sometimes differed from reactions with artificial inoculation in the greenhouse and growth chamber, usually more prone to express susceptibility.

Carnation is the most important cutflower crop in southwestern (SW) Spain and accounts for $45 \%$ of total production (Anonymous, 2004). The crop is mainly produced as a monoculture in plastic houses; rooted cuttings are planted in late spring (May to June) and removed after 22 to 23 months before preparation of the soil for new plantings. Consequently, populations of soilborne plant pathogens often increase to unacceptable levels.

The most important phytopathological problem affecting carnation in most areas of the world where the crop is grown is Fusarium wilt $(\mathrm{FW})$, incited by Fusarium oxysporum fsp. dianthi (Fod). FW affects carnations for most of the year when environmental conditions within the plastic house favor infection. Disease symptoms mostly occur in spring and early summer, when temperatures favor symptom expression (BenYephet et al., 1996). FW is prevalent in SW

Received for publication 18 Oct. 2006. Accepted for publication $26 \mathrm{Feb} .2007$.

${ }^{1}$ To whom reprint requests should be addressed; e-mailcsmevaj@uco.es
Spain, the site of over $70 \%$ of the national production of carnation (Anonymous, 2004), and susceptible cultivars suffer severe yield losses; considerable yield losses are also common in carnation cultivars previously described as resistant.

Carnation cultivars with race-specific resistance usually show low levels of disease under a range of environmental conditions; in contrast, cultivars with resistance to several Fod races show unstable and variable reactions to the disease (Ben-Yephet et al., 1997).

Garibaldi $(1975,1977)$ first reported Fod races 1 and 2 in Italy and France. Subsequently, six additional races (3 to 8) of Fod were reported (Aloi and Baayen, 1993; Garibaldi, 1983). Races 1 and 8, reported from Italy, France, and Spain, were associated with Mediterranean ecotypes of carnation, whereas race 2 is widespread in all carnation areas of the world. Race 4 was found in the United States, Colombia, Israel, Italy, and Spain, and races 5, 6 and 7 were found in the United Kingdom, France, and The Netherlands (Chiochetti et al., 1999; Garibaldi, 1983); the long-term maintenance of Fod isolates in the laboratory has led to changes in virulence patterns (Chiochetti et al., 1999).
Three new races of Fod have been reported recently, i.e., race 9 in Australia (Kalc Wright et al., 1996) and races 10 and 11 in The Netherlands (Baayen et al., 1997).

Cebolla et al. (1983) studied the importance of races 1 and 2 in Spanish soils and found a frequent and widespread distribution of race 2 in carnation crops in greenhouses, whereas with race 1 , frequency was high only in open-field crops in northeastern Spain. As a result of relocation in the last 30 years, half of the national carnation area in Spain is now in the SW, now the most important area for this crop (Navas Becerra, 1988). The race structure of Fod causing serious FW in SW Spain has yet to be determined.

Molecular markers for the determination of Fod races 2, 4, and, jointly, 1 and 8 were reported (Chiochetti et al., 1999), but attempts to use the markers for the determination of Fod races from SW Spain experienced variable specificity to the markers (Suárez Bonnet, 2007).

The widespread use of carnation cultivars described as resistant to FW in SW Spain has resulted in full or partial susceptibility of some carnation cultivars. There are also difficulties in finding replacements for the methyl bromide treatment of carnation FW. Therefore, this study had the following objectives: 1) to identify currently available carnation cultivars with satisfactory levels of resistance to races of Fod prevalent in southern Spain; and 2) to study the race distribution of Fod in carnation crops in SW Spain.

\section{Materials and Methods}

Resistance of carnation cultivars to Fusarium oxysporum $f s p$. dianthi. Three experiments (I, II, and III) were conducted to evaluate the resistance to Fod in the carnation cultivars most commonly grown for cutflower production in Andalusia (southern Spain).

Cultivars listed in Table 1 were tested with eight monosporic Fod isolates obtained from a greenhouse survey of carnation diseases conducted in SW Spain in 2001 to 2003 (Table 2). The isolates were representative of the range of virulence in the isolate collection. In addition, in Expt. I, cultivars Eilat, Elsy, Ivana Orange, Leila, Natila, Nelson, Peachy Intermezzo, Solar, and Yellow Twin were inoculated with 13 monosporic Fod isolates provided by the Laboratory of Plant Pathology of the University of Turin, Italy (Table 2).

Fod isolates were maintained in a sterile 2 sand : 1 silt (by volume) mixture at $5{ }^{\circ} \mathrm{C}$ until used. After $5 \mathrm{~d}$ of incubation at $24^{\circ} \mathrm{C}$, fungal colony disks (1-cm diameter) were transferred to flasks (four disks per flask) containing $150 \mathrm{~mL}$ sterile potato dextrose broth and incubated for $10 \mathrm{~d}$ on an orbital shaker at $150 \mathrm{rpm}, 24{ }^{\circ} \mathrm{C}$, and 12-h day/12-h night. Inocula were filtered through two layers of sterile gauze and diluted in sterile distilled water to give suspensions of $35 \times 10^{4}$ conidia/ $\mathrm{mL}$; the conidial suspensions were used to inoculate carnation cuttings by root-dipping 
Table 1. Degree of resistance to Fusarium oxysporum fsp. dianthi $(F o d)$ in 18 carnation cultivars used in Expts. I, II, and III according to commercial specifications

\begin{tabular}{ll}
\hline Cultivars & ${\text { Fod } \text { resistance }^{\mathrm{y}}}^{\mathrm{z}}$ \\
\hline Baltico & $\mathrm{RRRR} / 4$ \\
Castellaro & $\mathrm{RR} / 3$ \\
Celine & $\mathrm{RRR} / 3$ \\
Leila & $\mathrm{RR} / 4$ \\
Delphi & $\mathrm{RR} / 4$ \\
Eilat & $\mathrm{RRRR} / 4$ \\
Elsy & $\mathrm{RRRR} / 4$ \\
Epoca & $\mathrm{RRR} / 4$ \\
Ivana Orange & $\mathrm{RRR} / 3$ \\
Natila & - \\
Nelson & $\mathrm{RRRR} / 4$ \\
Orange Magic & $\mathrm{S}$ \\
Peachy Intermezzo & $\mathrm{RRRR} / 4$ \\
Scarlet King & $\mathrm{RRR} / 3$ \\
Solar & $\mathrm{RRR} / 4$ \\
Westcristal & $\mathrm{RRR} / 3$ \\
White Ashley & $\mathrm{R} / 3$ \\
Yellow Twin & $\mathrm{RRR} / 3$ \\
\hline
\end{tabular}

zThey were inoculated with Fod monosporic isolates A3-A7, P39, G1, and G2.

${ }^{\text {y }} \mathrm{S}=$ Susceptible to Fod. The numbers of R are indicative of increasing degree of resistance to Fod referred to the maximum of 3 or 4 as shown by the different producers.

Table 2. Monosporic isolates of Fusarium oxysporum fsp. dianthi (Fod) used in the experiments. $^{\mathrm{z}}$

\begin{tabular}{lll}
\hline Isolate & Origin & Race \\
\hline A3 & Spain $^{y}$ & - \\
A4 & Spain $^{y}$ & - \\
A5 & Spain $^{y}$ & - \\
A6 & Spain $^{y}$ & - \\
A7 & Spain $^{y}$ & - \\
P39 & Spain $^{y}$ & - \\
G1 & Spain $^{y}$ & - \\
G2 & Spain $^{y}$ & 1 \\
I-01 & Italy $^{x}$ & 1 \\
I-11 & Italy $^{x}$ & 1 \\
I-21 & Italy $^{x}$ & 2 \\
I-02 & Italy $^{x}$ & 2 \\
I-12 & Italy $^{x}$ & 2 \\
I-22 & Italy $^{x}$ & 4 \\
I-04 & Italy $^{x}$ & 4 \\
I-14 & Italy $^{x}$ & 4 \\
I-24 & Italy $^{x}$ & 6 \\
I-06 & Italy $^{x}$ & 8 \\
I-08 & Italy $^{x}$ & 8 \\
I-18 & Italy $^{x}$ & 8 \\
I-28 & Italy $^{x}$ & and
\end{tabular}

${ }^{\mathrm{z}}$ Isolates from Spain were used in Expts. I, II, and III. Isolates from Italy were used in Expt. I as testers for the determination of races of Fod.

${ }^{\mathrm{y}}$ Isolates obtained from SW Spain and maintained in the Laboratory of Crop Protection, IAS-CSIC, Córdoba, Spain.

'Isolates from the Laboratory of Plant Pathology, University of Turin, Italy.

for 5 min using $20 \mathrm{~mL}$ per plant. Inoculated cuttings were individually planted in pots with 2 sand : 1 silt : 2 peat (by volume) substrate and the remainder inoculum suspension added to it; the plants were transferred to growth chambers at $24{ }^{\circ} \mathrm{C}$ and $12-\mathrm{h}$ day/12-h night for 3 months.

Six to nine plants (replicates) were inoculated for each cultivar $\times$ isolate combination using a split-plot design with isolate as the main plot and cultivar as the subplot. Fusarium wilt symptoms were evaluated weekly for 3 months using the scale: $1=$ no symptoms; $2=$ chlorosis of plant base; $3=$ chlorosis or wilt of the third to half basal part of the plant; $4=$ wilt reaching at least one branch of the upper part of the plant; and $5=$ dead plant. Intermediate values were also recorded. Carnation cultivars with an average symptom severity of 1.5 or greater at the end of the experiment were considered to be susceptible to the corresponding Fod isolate used for inoculation. Areas under the curves of the time course of symptom severity for each plant were calculated and standardized over time (SAUCS). Analysis of variance was applied to the SAUCS values for every experiment and the means of statistically different treatments $(P=0.01)$ were compared using Tukey's tests.

Phenotypic determination of races of Fusarium oxysporum $f_{s p}$. dianthi. Ninety monosporic Fod isolates from SW Spain, including isolates A3, A4, A5, A6, A7, P39, $\mathrm{G} 1$, and $\mathrm{G} 2$, used as previously, together with the 13 isolates from Italy (Table 2), were used to inoculate the carnation cultivars listed in Table 3 for which the reactions to the different races of Fod are shown. The experiment was repeated three times. The isolates were inoculated using the methods in the previous section. Inoculated carnation cuttings were grown in a greenhouse at 18 to $30{ }^{\circ} \mathrm{C}$ and 11- to 13-h daylength. Six to eight replicates (one plant per replicate) were used for each cultivar $\times$ isolate combination. Fusarium wilt symptoms were evaluated as before; a mean severity of 1.5 was considered to differentiate susceptible from resistant reactions.

\section{Results and Discussion}

Resistance of different carnation cultivars to Fusarium oxysporum $f s p$. dianthi. Cultivars Baltico, Castellaro, Celine, Delphi, Natila, Nelson, Orange Magic, Solar, and White Ashley were susceptible to all Spanish isolates of Fod tested. Cultivars Eilat, Ivana Orange, Leila, Peachy Intermezzo, and Yellow Twin were resistant to isolates G1 and G2. Cultivar Elsy was susceptible to isolates G1 and G2 but resistant to all other isolates tested (A3-A7 and P39) and cultivar Westcristal was also fully resistant to A3-A7 and P39 (Table 4).

Cultivars Epoca and Peachy Intermezzo showed resistant reactions to inoculation with A6. Variable reactions were observed with cultivar Scarlet King when inoculated with isolates A4, A6, and A7 in contrast with the consistent susceptible reactions to A3 and A5 and consistent resistance reactions to isolate P39 (Table 4).

SAUCS analysis of variance showed significant differences between isolates, cultivars, and their interaction $(P=0.0001)$ for the three experiments carried out. The three experiments showed similar values of symptom severity. Apart from isolates G1 and G2, which were inoculated only to eight cultivars, isolates A6 and P39 were the
Table 3. Phenotypic determination of races of Fusarium oxysporum fsp. dianthi $($ Fod $){ }^{\mathrm{z}}$

\begin{tabular}{lccccc}
\hline Cultivars & R1 & R2 & R4 & R6 & R8 \\
\hline Annelies & $\mathrm{S}^{\mathrm{y}}$ & $\mathrm{S}$ & $\mathrm{S}$ & $\mathrm{S}$ & $\mathrm{S}$ \\
Eilat & $\mathrm{R}$ & $\mathrm{S}$ & $\mathrm{R}$ & $\mathrm{R}$ & $\mathrm{R}$ \\
Etna & $\mathrm{R}$ & $\mathrm{S}$ & $\mathrm{S}$ & $\mathrm{S}$ & $\mathrm{S}$ \\
Exotica & $\mathrm{R}$ & $\mathrm{S}$ & $\mathrm{S}$ & $\mathrm{S}$ & $\mathrm{R}$ \\
Roberta & $\mathrm{S}$ & $\mathrm{S}$ & $\mathrm{S}$ & $\mathrm{S}$ & $\mathrm{S}$ \\
Sangria & $\mathrm{R}$ & $\mathrm{S}$ & $\mathrm{R}$ & $\mathrm{S}$ & $\mathrm{S}$ \\
Solar & $\mathrm{S}$ & $\mathrm{S}$ & $\mathrm{S}$ & $\mathrm{R}$ & $\mathrm{R}$ \\
\hline
\end{tabular}

${ }^{\mathrm{z} C o m p i l e d ~ f r o m ~ G a r i b a l d i ~(1983) ~ a n d ~ P r a d o s-~}$ Ligero et al. (2003).

${ }^{\text {y }} \mathrm{S}=$ Susceptible to Fod (symptom severity 1.5 or greater using a symptom severity scale $1-5)$. R = Resistant to Fod (symptom severity less than 1.5 using a symptom severity scale $1-5$ ).

least virulent and $\mathrm{A} 3$ the most virulent (Table 4).

Regardless of experiment, cultivars Delphi and Orange Magic were the most susceptible. Most of the carnation cultivars tested (Baltico, Castellaro, Celine, Eilat, Leila, Natila, Nelson, White Ashley, and Yellow Twin) showed similar reactions to the Spanish isolates A3-A7 and P39 of Fod; the cultivars were susceptible to all the isolates, whereas cultivars Elsy and Westcristal were resistant to all the isolates tested (Table 5).

Cultivars Eilat, Ivana Orange, Leila, Peachy Intermezzo, and Yellow Twin significantly differentiated isolates G1 and G2 from other isolates, whereas 'Scarlet King' showed full resistance to P39 (Table 5).

Cultivars Elsy, Eilat, and Yellow Twin proved to be the most resistant against Italian isolates of Fod. Cultivar Elsy was susceptible only to isolates of race 1, 'Eilat' only to isolates of race 2, and 'Yellow Twin' was susceptible only to isolate I-22 (race 2) (Table 6). In contrast, cultivar Leila was susceptible to isolates of races 2, 4, and 6, whereas 'Solar' was susceptible to races 1, 2, and 4 of Fod, and 'Peachy Intermezzo' and 'Ivana Orange' were susceptible to races 2, 6, and 8 of Fod; inconsistent reactions were observed with cultivar Ivana Orange when inoculated with two isolates of race 4 (Table 6).

Spanish isolates A3-A7 caused FW symptoms in all carnation cultivars evaluated except 'Westcristal' and 'Elsy', the latter showing only mild symptoms when inoculated with A3 and A7. In contrast, Fod isolates G1 and G2 did not cause FW symptoms in cultivars Eilat, Ivana Orange, Leila, Peachy Intermezzo, and Yellow Twin (Table 4). A similar reaction was confirmed with cultivars Eilat, Leila, and Yellow Twin inoculated with the Italian isolates of races 1 and 8. Cultivar Nelson was susceptible to Italian isolates of races 1 and 8; cultivars Elsy, Natila, and Solar were susceptible to race 1 and resistant to race 8 ; and cultivar Peachy Intermezzo was susceptible to race 8 and resistant to race 1 . Therefore, these cultivars could be used as differentials for both races. Cultivars Peachy Intermezzo, Eilat, and Yellow Twin were susceptible to race 2 and resistant to race 4; therefore, they could be used to differentiate between the two races (Table 6). 
Table 4. Resistance of different carnation cultivars inoculated ${ }^{\mathrm{z}}$ with Spanish isolates of Fusarium oxysporum fsp. dianthi (Fod).

\begin{tabular}{|c|c|c|c|c|c|c|c|c|c|c|c|c|c|c|c|c|}
\hline \multirow{2}{*}{$\frac{\text { Cultivars }}{\text { Baltico }}$} & \multicolumn{2}{|c|}{ A3 } & \multicolumn{2}{|c|}{ A4 } & \multicolumn{2}{|c|}{ A5 } & \multicolumn{2}{|c|}{ A6 } & \multicolumn{2}{|c|}{ A7 } & \multicolumn{2}{|c|}{ P39 } & \multicolumn{2}{|c|}{ G1 } & \multicolumn{2}{|c|}{ G2 } \\
\hline & $4.9^{y}$ & $\mathrm{~S}^{\mathrm{x}}$ & 4.4 & $\mathrm{~S}$ & 4.8 & $\mathrm{~S}$ & 3.7 & $\mathrm{~S}$ & 2.8 & $\mathrm{~S}$ & 4.8 & $\mathrm{~S}$ & - & - & - & - \\
\hline Castellaro & 5.0 & $\mathrm{~S}$ & 5.0 & S & 5.0 & $\mathrm{~S}$ & 5.0 & $\mathrm{~S}$ & 5.0 & $\mathrm{~S}$ & 5.0 & $\mathrm{~S}$ & - & - & - & - \\
\hline Celine & 4.7 & $\mathrm{~S}$ & 4.7 & $\mathrm{~S}$ & 4.2 & $\mathrm{~S}$ & 2.0 & $\mathrm{~S}$ & 2.0 & $\mathrm{~S}$ & 3.5 & $\mathrm{~S}$ & - & - & - & - \\
\hline Delphi & 4.6 & $\mathrm{~S}$ & 5.0 & $\mathrm{~S}$ & 4.8 & $\mathrm{~S}$ & 4.8 & $\mathrm{~S}$ & 4.9 & $\mathrm{~S}$ & - & - & - & - & - & - \\
\hline Eilat & 4.8 & $\mathrm{~S}$ & 4.0 & $\mathrm{~S}$ & 4.0 & $\mathrm{~S}$ & 4.0 & $\mathrm{~S}$ & 4.1 & $\mathrm{~S}$ & 3.5 & $\mathrm{~S}$ & 1.0 & $\mathrm{R}$ & 1.0 & $\mathrm{R}$ \\
\hline Elsy & 1.2 & $\mathrm{R}$ & 1.0 & $\mathrm{R}$ & 1.0 & $\mathrm{R}$ & 1.0 & $\mathrm{R}$ & 1.3 & $\mathrm{R}$ & 1.0 & $\mathrm{R}$ & 5.0 & $\mathrm{~S}$ & 5.0 & $\mathrm{~S}$ \\
\hline Epoca & 3.9 & $\mathrm{~S}$ & 4.6 & S & 5.0 & $\mathrm{~S}$ & 1.0 & $\mathrm{R}$ & 4.4 & $\mathrm{~S}$ & - & - & - & - & - & - \\
\hline Ivana Orange & 5.0 & $\mathrm{~S}$ & 4.4 & $\mathrm{~S}$ & 4.8 & $\mathrm{~S}$ & 3.0 & $\mathrm{~S}$ & 4.5 & $\mathrm{~S}$ & 4.8 & $\mathrm{~S}$ & 1.0 & $\mathrm{R}$ & 1.0 & $\mathrm{R}$ \\
\hline Leila & 4.0 & $\mathrm{~S}$ & 3.3 & S & 4.1 & $\mathrm{~S}$ & 2.9 & $\mathrm{~S}$ & 3.3 & $\mathrm{~S}$ & 2.9 & $\mathrm{~S}$ & 1.0 & $\mathrm{R}$ & 1.0 & $\mathrm{R}$ \\
\hline Natila & 4.7 & $\mathrm{~S}$ & 3.2 & $\mathrm{~S}$ & 4.0 & $\mathrm{~S}$ & 1.5 & $\mathrm{~S}$ & 3.2 & $\mathrm{~S}$ & 1.7 & $\mathrm{~S}$ & - & - & - & - \\
\hline Nelson & 4.7 & $\mathrm{~S}$ & 3.7 & S & 4.6 & $\mathrm{~S}$ & 3.9 & $\mathrm{~S}$ & 3.6 & $\mathrm{~S}$ & 4.0 & $\mathrm{~S}$ & 5.0 & $\mathrm{~S}$ & 5.0 & $\mathrm{~S}$ \\
\hline Orange Magic & 5.0 & $\mathrm{~S}$ & 5.0 & $\mathrm{~S}$ & 4.9 & $\mathrm{~S}$ & 3.5 & $\mathrm{~S}$ & 4.8 & $\mathrm{~S}$ & - & - & - & - & - & 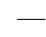 \\
\hline Peachy Intermezzo & 2.9 & $\mathrm{~S}$ & 3.9 & $\mathrm{~S}$ & 3.7 & $\mathrm{~S}$ & 1.3 & $\mathrm{R}$ & 3.7 & $\mathrm{~S}$ & 3.1 & $\mathrm{~S}$ & 1.0 & $\mathrm{R}$ & 1.0 & $\mathrm{R}$ \\
\hline Scarlet King & 4.3 & $\mathrm{~S}$ & 2.0 & $\mathrm{~S}$ & 3.8 & $\mathrm{~S}$ & 1.8 & $\mathrm{~S}$ & 2.0 & $\mathrm{~S}$ & 1.0 & $\mathrm{R}$ & - & - & - & - \\
\hline Solar & 3.6 & $\mathrm{~S}$ & 4.2 & $\mathrm{~S}$ & 4.1 & $\mathrm{~S}$ & 4.0 & $\mathrm{~S}$ & 3.6 & $\mathrm{~S}$ & 4.8 & $\mathrm{~S}$ & 5.0 & $\mathrm{~S}$ & 5.0 & $\mathrm{~S}$ \\
\hline Westcristal & 1.0 & $\mathrm{R}$ & 1.0 & $\mathrm{R}$ & 1.0 & $\mathrm{R}$ & 1.0 & $\mathrm{R}$ & 1.0 & $\mathrm{R}$ & 1.0 & $\mathrm{R}$ & - & - & - & - \\
\hline White Ashley & 5.0 & $\mathrm{~S}$ & 3.3 & $\mathrm{~S}$ & 5.0 & $\mathrm{~S}$ & 3.0 & $\mathrm{~S}$ & 3.8 & $\mathrm{~S}$ & 3.0 & $\mathrm{~S}$ & - & - & - & - \\
\hline Yellow Twin & 4.1 & $\mathrm{~S}$ & 3.3 & $\mathrm{~S}$ & 3.7 & $\mathrm{~S}$ & 5.0 & $\mathrm{~S}$ & 2.1 & $\mathrm{~S}$ & 2.3 & $\mathrm{~S}$ & 1.0 & $\mathrm{R}$ & 1.0 & $\mathrm{R}$ \\
\hline
\end{tabular}

${ }^{\mathrm{z}}$ Inoculation was performed by dipping carnation roots in suspensions of $35 \times 10^{4}$ conidia/mL ( $20 \mathrm{~mL}$ per plant) of the corresponding Fod isolate during 5 min before individual transplanting to pots with 2 sand : 1 silt : 2 peat (by volume) sterile mixture, which were incubated for 3 months in a growth chambers at $24{ }^{\circ} \mathrm{C}$ and 12 -h day/12-h night.

${ }^{y}$ Average symptom severity values at the end of Expts. I, II, and III according to a scale 1-5.

${ }^{\mathrm{x}} \mathrm{S}=$ susceptible; $\mathrm{R}=$ resistant overall reactions, considering 1.5 as the minimum severity value for susceptibility.

Table 5. Average SAUCS values of carnation cultivars inoculated with different Fusarium oxysporum fsp. dianthi (Fod) Spanish isolates.

\begin{tabular}{|c|c|c|c|c|c|c|c|c|}
\hline \multirow[b]{2}{*}{ Cultivars } & \multicolumn{8}{|c|}{ Isolates of Fod from Spain } \\
\hline & A3 & A4 & A5 & A6 & A7 & P-39 & G1 & G2 \\
\hline Baltico & $4.6 \pm 0.5^{z}$ & $3.8 \pm 1.4$ & $4.3 \pm 0.4$ & $3.6 \pm 3.0$ & $4.0 \pm 3.9$ & $3.5 \pm 0.4$ & & \\
\hline Castellaro & $4.3 \pm 0.2$ & $3.9 \pm 1.1$ & $4.2 \pm 0.2$ & $3.8 \pm 0.7$ & $4.1 \pm 0.3$ & $4.0 \pm 0.4$ & & \\
\hline Celine & $3.5 \pm 0.7$ & $3.6 \pm 0.4$ & $3.2 \pm 0.7$ & $1.5 \pm 1.2$ & $2.0 \pm 2.5$ & $2.9 \pm 1.6$ & & \\
\hline Delphi & $4.1 \pm 0.6$ & $5.0 \pm 0.6$ & $4.3 \pm 0.9$ & $4.8 \pm 1.3$ & $6.0 \pm 0.4$ & & & \\
\hline Eilat & $2.8 \pm 0.8$ & $2.2 \pm 1.2$ & $2.2 \pm 4.0$ & $2.4 \pm 3.6$ & $2.6 \pm 3.5$ & $1.6 \pm 1.6$ & $0.0 \pm 0.0$ & $0.0 \pm 0.0$ \\
\hline Elsy & $0.4 \pm 1.3$ & $0.0 \pm 0.0$ & $0.0 \pm 0.0$ & $0.0 \pm 0.0$ & $0.2 \pm 4.0$ & $0.0 \pm 0.0$ & $0.2 \pm 0.01$ & $0.2 \pm 0.03$ \\
\hline Epoca & $3.5 \pm 1.1$ & $2.0 \pm 0.6$ & $2.8 \pm 0.4$ & $1.0 \pm 0.0$ & $1.7 \pm 0.6$ & & & \\
\hline Ivana Orange & $2.1 \pm 1.9$ & $2.0 \pm 1.9$ & $2.2 \pm 2.1$ & $0.5 \pm 1.3$ & $2.1 \pm 2.0$ & $2.2 \pm 0.1$ & $0.0 \pm 0.0$ & $0.0 \pm 0.0$ \\
\hline Leila & $1.5 \pm 2.0$ & $1.4 \pm 1.4$ & $1.7 \pm 1.6$ & $2.2 \pm 2.2$ & $1.7 \pm 1.5$ & $0.8 \pm 1.0$ & $0.0 \pm 0.0$ & $0.0 \pm 0.0$ \\
\hline Natila & $3.8 \pm 0.7$ & $2.7 \pm 0.6$ & $3.2 \pm 0.5$ & $1.2 \pm 1.3$ & $2.7 \pm 1.4$ & $1.5 \pm 1.7$ & & \\
\hline Nelson & $2.9 \pm 2.2$ & $3.2 \pm 3.2$ & $2.9 \pm 2.2$ & $2.6 \pm 2.1$ & $3.2 \pm 3.0$ & $1.7 \pm 1.6$ & $0.2 \pm 0.02$ & $0.2 \pm 0.01$ \\
\hline Orange Magic & $5.0 \pm 0.3$ & $4.7 \pm 0.5$ & $4.6 \pm 0.3$ & $3.6 \pm 1.6$ & $4.1 \pm 0.5$ & & & \\
\hline Peachy Intermezzo & $1.6 \pm 2.0$ & $2.3 \pm 2.1$ & $2.0 \pm 1.6$ & $0.8 \pm 1.3$ & $0.9 \pm 1.6$ & $1.0 \pm 0.03$ & $0.0 \pm 0.0$ & $0.0 \pm 0.0$ \\
\hline Scarlet King & $1.7 \pm 1.8$ & $2.8 \pm 2.3$ & $1.5 \pm 1.7$ & $1.0 \pm 1.4$ & $1.1 \pm 1.7$ & $0.0 \pm 0.0$ & & \\
\hline Solar & $2.3 \pm 1.7$ & $4.3 \pm 2.0$ & $4.6 \pm 3.8$ & $0.0 \pm 0.0$ & $4.8 \pm 2.1$ & $0.2 \pm 0.03$ & $0.2 \pm 0.0$ & $0.2 \pm 0.01$ \\
\hline Westcristal & $0.0 \pm 0.0$ & $0.0 \pm 0.0$ & $0.0 \pm 0.0$ & $0.0 \pm 0.0$ & $0.0 \pm 0.0$ & $0.0 \pm 0.0$ & & \\
\hline White Ashley & $3.9 \pm 0.5$ & $2.4 \pm 1.5$ & $4.0 \pm 0.5$ & $3.9 \pm 1.6$ & $3.0 \pm 1.6$ & $1.8 \pm 2.0$ & & \\
\hline Yellow Twin & $2.2 \pm 2.1$ & $2.1 \pm 2.2$ & $2.0 \pm 2.0$ & $1.7 \pm 1.7$ & $1.0 \pm 1.1$ & $1.3 \pm 1.6$ & $0.0 \pm 0.0$ & $0.0 \pm 0.0$ \\
\hline
\end{tabular}

${ }^{\mathrm{z} E a c h}$ value indicates the average of standardized area under the curve of symptom severity along the period of evaluation followed by the standard deviation of the values.

Table 6. Resistance of different carnation cultivars inoculated ${ }^{\mathrm{z}}$ with Italian isolates of Fusarium oxysporum fsp. dianthi (Fod).

\begin{tabular}{|c|c|c|c|c|c|c|c|c|c|c|c|c|c|}
\hline \multirow[b]{2}{*}{ Cultivars } & \multicolumn{3}{|c|}{ Race 1} & \multicolumn{3}{|c|}{ Race 2} & \multicolumn{3}{|c|}{ Race 4} & \multirow{2}{*}{$\frac{\text { Race } 6}{I-06}$} & \multicolumn{3}{|c|}{ Race 8} \\
\hline & $\overline{\mathrm{I}-01}$ & $\mathrm{I}-11$ & $\mathrm{I}-21$ & $\mathrm{I}-02$ & $\mathrm{I}-12$ & $\mathrm{I}-22$ & $\mathrm{I}-04$ & I-14 & $\mathrm{I}-24$ & & $\mathrm{I}-08$ & I-18 & $\mathrm{I}-28$ \\
\hline Eilat & $1.0^{\mathrm{y}}$ & 1.0 & $1.0 \mathrm{R}^{\mathrm{x}}$ & - & 3.6 & $3.6 \mathrm{~S}$ & 1.0 & 1.0 & $1.0 \mathrm{R}$ & $1.3 \mathrm{R}$ & 1.0 & 1.0 & $1.0 \mathrm{R}$ \\
\hline Elsy & 2.1 & 4.5 & $4.6 \mathrm{~S}$ & - & 1.0 & $1.0 \mathrm{R}$ & 1.0 & 1.0 & $1.6 \mathrm{R} / \mathrm{S}$ & $1.1 \mathrm{R}$ & 1.0 & 1.0 & $1.0 \mathrm{R}$ \\
\hline Ivana Orange & - & 1.7 & $1.0 \mathrm{R} / \mathrm{S}$ & 3.2 & 2.4 & $-\mathrm{S}$ & - & 1.0 & $3.7 \mathrm{~S} / \mathrm{R}$ & $1.7 \mathrm{~S}$ & - & 2.7 & $-\mathrm{S}$ \\
\hline Leila & 1.0 & 1.0 & $1.0 \mathrm{R}$ & - & 2.9 & $3.0 \mathrm{~S}$ & 2.1 & 1.9 & $3.6 \mathrm{~S}$ & $2.3 \mathrm{~S}$ & 1.0 & 1.0 & $1.0 \mathrm{R}$ \\
\hline Natila & 2.3 & 4.2 & $-\mathrm{S}$ & - & & $1.2 \mathrm{R}$ & 2.2 & - & $3.0 \mathrm{~S}$ & $1.3 \mathrm{R}$ & 1.0 & 1.0 & $-\mathrm{R}$ \\
\hline Nelson & - & 3.9 & $5.0 \mathrm{~S}$ & - & 3.5 & $2.9 \mathrm{~S}$ & 5.0 & 4.8 & $5.0 \mathrm{~S}$ & $2.3 \mathrm{~S}$ & 3.4 & 3.4 & $1.3 \mathrm{~S}$ \\
\hline Peachy Intermezzo & 1.0 & 1.0 & $1.0 \mathrm{R}$ & 2.7 & 4.2 & $4.7 \mathrm{~S}$ & 1.0 & 1.0 & $1.0 \mathrm{R}$ & $2.4 \mathrm{~S}$ & - & 3.7 & $2.8 \mathrm{~S}$ \\
\hline Solar & 1.0 & 4.4 & $5.0 \mathrm{~S} / \mathrm{R}$ & 2.8 & 2.3 & $4.8 \mathrm{~S}$ & 5.0 & 5.0 & $5.0 \mathrm{~S}$ & $1.3 \mathrm{R}$ & - & 1.5 & $1.0 \mathrm{R} / \mathrm{S}$ \\
\hline Yellow Twin & 1.0 & 1.0 & $1.0 \mathrm{R}$ & & 1.0 & $4.2 \mathrm{~S} / \mathrm{R}$ & 1.0 & 1.0 & $1.3 \mathrm{R}$ & $1.0 \mathrm{R}$ & 1.0 & 1.0 & $1.0 \mathrm{R}$ \\
\hline
\end{tabular}

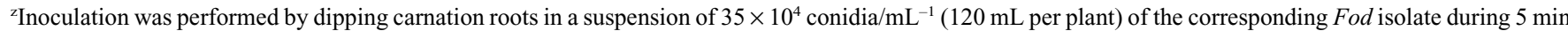
before individual transplanting to pots with 2 sand : 1 silt : 2 peat (by volume) sterile mixture, which were incubated for 3 months in a growth chamber at $24{ }^{\circ} \mathrm{C}$ and 12-h day/12-h night.

${ }^{y}$ Average symptom severity values at the end of Expt. I according to a scale $1-5$.

${ }^{\mathrm{x}} \mathrm{S}=$ susceptible; $\mathrm{R}=$ resistant overall reactions, considering 1.5 as the minimum severity value for susceptibility; $\mathrm{S} / \mathrm{R}$ or $\mathrm{R} / \mathrm{S}=$ reactions of susceptibility or resistance depending on the isolates inoculated of the given race.

Although the Spanish isolates A3-A7 and P39 have been assigned to race 2, our results indicate a variable reaction in cultivar Scarlet King to race 2 of Fod. The results of
Ben-Yephet et al. (1997) indicated a symptomless reaction of 'Scarlette' to race 2 (Sparnaaij and Demmink, 1997). This discrepancy suggests the occurrence of genetic diversity within race 2 or an environmentdependent response (Ben-Yephet et al., 1996; Ben-Yephet and Shtienberg, 1997) of cultivar Scarlette, as occurred with cultivar Carrier 
929, which showed FW symptoms at $26{ }^{\circ} \mathrm{C}$ but not at $22{ }^{\circ} \mathrm{C}$ (Harling et al., 1988).

Phenotypic determination of races of Fusarium oxysporum $f_{s p}$. dianthi. Of 90 Spanish isolates of Fod obtained from the most important areas of carnation crops in Spain, six isolates (designed as 1, 6, 52, 79, $\mathrm{G} 1$, and G2) belonged to race 1 and the remainder caused the typical reactions of race 2 when inoculated to the differential cultivars listed in Table 3. Isolates A3, A4, A5, A6, A7, and P39, used in the previous experiments, were found among the Spanish isolates determined as race 2 .

The inheritance of genetic resistance to Fod is controversial and may vary with the races of the pathogen. Demmink et al. (1989) suggested that resistance to race 1 of Fod is monogenic and dominant, whereas Baayen et al. (1991) concluded that resistance could be determined by one or several genes. Resistance of carnation cultivars to race 2 is usually partial and polygenic and is expressed as a complex of host reactions (Sparnaaij and Demmink, 1997). Zuker et al. (2000) observed genetic segregation in the progeny of 'Scarlette' that leads to loss of resistance to the pathogen.

Cultivar Elsy showed resistance to all the isolates of races $2,4,6$, and 8 tested, except for a slight susceptibility to isolate I-24, but was susceptible to isolates of race 1 . This is in agreement with Garibaldi (1978) but differs from the reaction of moderate resistance to race 2 of the pathogen (Demmink et al., 1989). The discrepancy could be explained by differences in environmental conditions during incubation and in the method of inoculation. Because specificity of host-pathogen interactions and environmental conditions contribute to disease severity, inconsistent results from different experiments conducted under different conditions are not unexpected (Ben-Yephet et al., 1997).

Our results confirm those of Garibaldi (1977, 1978) with regard to the wide range of virulence of Fod isolates regardless of the races to which they belong. Pathogenicity tests conducted under a controlled environment in growth chambers or greenhouses are useful to evaluate the resistance or susceptibility of carnation cultivars to particular isolates of the pathogen but do not predict the degree of resistance under conditions in commercial greenhouses where different races frequently occur together (Ben-Yephet et al., 1993). Under such conditions, resistance to Fod might be shown as a delay in the onset of an epidemic or a reduction in the rate of disease progress compared with susceptible cultivars (Melero-Vara et al., 2005). Therefore, artificial inoculation of carnation cuttings grown in pots usually provides evidence of the potential of virulence that would not necessarily coincide with the reactions under natural conditions (Ben-Yephet and Shtienberg, 1997).

\section{Literature Cited}

Aloi, C. and R.P. Baayen. 1993. Examination of the relationships between vegetative compatibility groups and races in Fusarium oxysporum fsp. dianthi. Plant Pathol. 42:839-850.

Anonymous. 2004. Anuario de Estadística Agroalimentaria. Cap. 12:1-13. Ministerio de Agricultura Pesca y Alimentación. Spain.

Baayen, R.P., L.D. Sparnaaij, J. Jansen, and G.J. Niemann. 1991. Inheritance of resistance in carnation against Fusarium oxysporum fsp. dianthi races 1 and 2 , in relation to resistance components. Neth. J. Plant Pathol. 97: $73-86$.

Baayen, R.P., F. van Dreven, M.C. Krijger, and C. Wallwijk. 1997. Genetic diversity in Fusarium oxysporum fsp. dianthi and Fusarium redolens fsp. dianthi. Eur. J. Plant Pathol. 103:395408.

Ben-Yephet, Y., M. Reuven, and Y. Mor. 1993. Selection methods for determining resistance of carnation cultivars to Fusarium oxysporum fsp. dianthi. Plant Pathol. 42:517-521.

Ben-Yephet, Y., M. Reuven, and D. Shtienberg. 1997. Complete resistance by carnation cultivars to Fusarium wilt induced by Fusarium oxysporum fsp. dianthi race 2. Plant Dis. 81:777-780.

Ben-Yephet, Y., M. Reuven, A. Zveibil, and D. Shtienberg. 1996. Effects of abiotic variables on the response of carnation cultivars to Fusarium oxysporum fsp. dianthi. Plant Pathol. 45:98-105.

Ben-Yephet, Y. and D. Shtienberg. 1997. Effects of the host, the pathogen, the environment and their interactions, on Fusarium wilt in carnation. Phytoparasitica 25:207-216.

Cebolla, V., C. Monton, P. Carrasco, and A. Rodríguez. 1983. La importancia de las razas Iy II de Fusarium oxysporum fsp. dianthi en los suelos españoles. Jornadas sobre Patología Vegetal. Monografía INIA 48. Ministerio de Agricultura, Pesca y Alimentación (ed.). Madrid, Spain.

Chiochetti, A., I. Bernardo, M. Daboussi, A. Garibaldi, M.L. Gullino, T. Langin, and Q. Migheli. 1999. Detection of Fusarium oxysporum fsp. dianthi in carnation tissue by PCR amplification of transposon insertions. Phytopathology 89:1169-1175.

Demmink, J.F., R.P. Baayen, and L.D. Sparnaaij. 1989. Evaluation of the virulence of race 1, 2 and 4 of Fusarium oxysporum fsp. dianthi in carnation. Euphytica 42:55-63.

Garibaldi, A. 1975. Race differentiation in Fusarium oxysporum fsp. dianthi (Prill et Del.). Snyd. et Hans. First Contribution. Med. Fac. Landbouww. Rijks Univ. Gent. 40:531537.

Garibaldi, A. 1977. Race differentiation in Fusarium oxysporum fsp. dianthi and varietal susceptibility. Acta Hort. 71:97-101.

Garibaldi, A. 1978. Susceptibility of carnation to Italian isolates of Fusarium oxysporum fsp. dianthi and Fusarium oxysporum var. redolens, p. 141-148. In: Proceedings of the Eucarpia Meeting on Carnation and Gerbera. Alassio, Italy.

Garibaldi, A. 1983. Resistenza di cultivar di garofano nei confronti di otto patotipi di Fusarium oxysporum fsp. dianthi (Prill. et Del.). Snyd et Hans. Riv. Ortoflorofrutt. Italiana 67:261-270.

Harling, R., G.S. Taylor, P. Matthews, and A.E. Arthur. 1988. The effect of temperature on symptom expression and colonization in resistant and susceptible carnation cultivars infected with Fusarium oxysporum fsp. dianthi. J. Phytopathol. 121:103-117.

Kalc Wright, G.F., D.I. Guest, D.L.S. Wimalajeewa, and R. van Heeswijck. 1996. Characterization of Fusarium oxysporum isolated from carnation in Australia based on pathogenicity, vegetative compatibility and random amplified polymorphic DNA (RAPD) assay. Eur. J. Plant Pathol. 102:451-457.

Melero-Vara, J.M., A.M. Prados, M.J. Basallote, and C.J. López-Herrera. 2005. Physical and chemical methods of controlling Fusarium wilt of carnation as alternatives to methyl bromide treatments. Acta Hort. 698:175-179.

Navas Becerra, J.A. 1988. Apuntes sobre el cultivo del clavel. Consejería de Agricultura y Pesca (ed.). Junta de Andalucía. Sevilla, Spain.

Prados-Ligero, A.M., J.M. Melero-Vara, and M.J. Basallote-Ureba. 2003. Evaluation of levels of resistance to Fusarium oxysporum fsp. dianthi in some carnation cultivars. Page 363. In: Proceedings of 8th International Congress of Plant Pathology, vol. 2. Christchurch, New Zealand.

Suárez Bonnet, E. 2007. Caracterización racial de Fusarium oxysporum fsp. dianthi y determinación de su viabilidad en suelos sometidos a diferentes regímenes térmicos. Universidad de Córdoba, Spain, PhD Thesis.

Sparnaaij, L.D. and J.F. Demmink. 1997. Progress towards Fusarium resistance in carnations. Acta Hort. 71:107-113.

Zuker, A., E. Shklarman, H. Scovel, H. Ben-Meir, M. Ovadis, I. Neta-Sharir, Y. Ben-Yephet, D. Weiss, A. Watad, and A. Vainstein. 2000. Genetic engineering of agronomic and ornamental traits in carnation. Proceeding of In vitro culture and horticultural Breeding ISHS, Finland. 